\section{Screening for steatorrhoea with an oxalate loading test}

The tedium and unpleasantness of collecting faeces to measure the excretion of fat have provoked a search for other ways of screening for steatorrhoea. Malabsorption of fat is associated with hyperoxaluria due to enhanced intestinal absorption of oxalate, ${ }^{1-3}$ which has led to measurement of 24 hour urinary oxalate excretion after an oral oxalate load being used as a screening test for steatorrhoea ${ }^{4}{ }^{5}$ In the test of Andersson and Gillberg the oral load was given as spinach, ${ }^{4}$ but the availability of oxalate from this source varies. ${ }^{5}$ Our earlier test required the patient to take a defined diet for a week as well as a three day sodium oxalate load. ${ }^{5}$ We now describe a similar test simplified by the abolition of dietary restriction and by the administration of sodium oxalate for only two days.

\section{Patients, methods, and results}

We studied 50 patients aged 18-84 with suspected malabsorption of fat, six of whom were outpatients. They were all taking an unrestricted diet and were given $300 \mathrm{mg}$ sodium oxalate daily in gelatin capsules dissolved in $200 \mathrm{ml}$ of water with lunch and supper for two days. On the second day a 24 hour urine specimen was collected and over days 1-3 a three day faecal specimen was collected. Urinary oxalate (using the oxalate decarboxylase method), urinary creatinine, and faecal fat excretions were measured as described previously 5 Patients with known colonic or renal disease were prospectively excluded from the study, and others were retrospectively excluded because of incomplete collection of urine as indicated by urinary creatinine excretion $<6 \mathrm{mmol}(679 \mathrm{mg}) / 24 \mathrm{~h}$ (17 patients); failure to take the oxalate capsules (one patient); or deficient collection of faecal specimens ( $<65 \mathrm{~g}$ in three days) (14 patients).

The figure shows the excretion of urinary oxalate and faecal fat and the final diagnoses in the 50 patients studied. Of the 25 patients with steatorrhoea

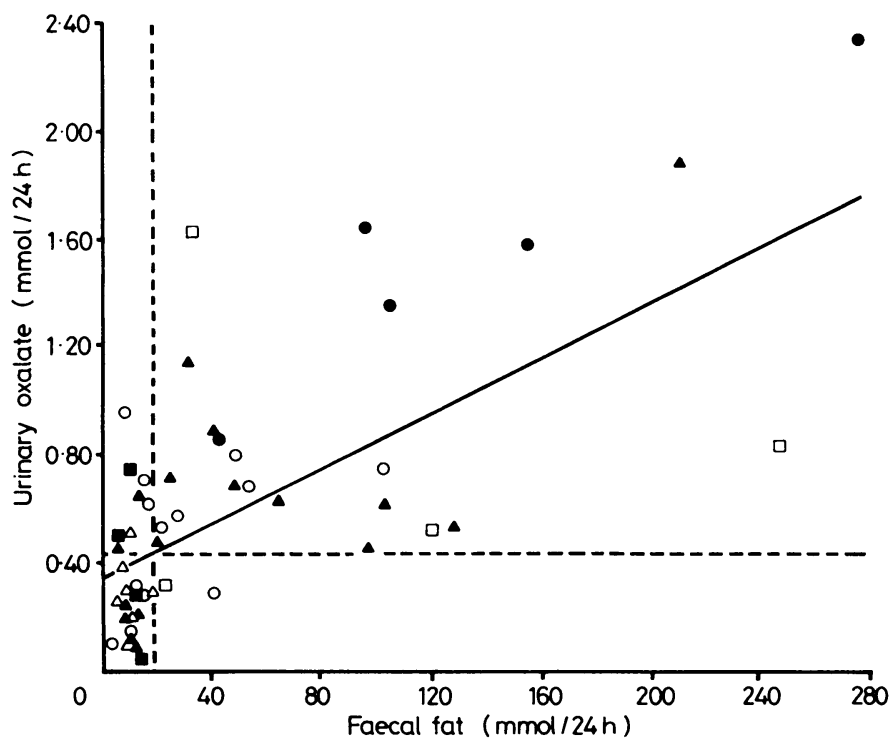

Twenty four hour urinary oxalate and faecal fat excretions in $\mathbf{5 0}$ patients with: Crohn's disease $(O)$; jejunoileal bypass $(O)$; pancreatic insufficiency $(\square)$; recurrent acute pancreatitis $(\boldsymbol{\Xi})$; irritable bowel syndrome $(\Delta)$; or other diagnoses $(\boldsymbol{\Delta})$ (after gastrectomy (3), after vagotomy (1), small-bowel resection (2), small-bowel contamination (2), coeliac disease (2), radiation enteritis (1), treatment with mefenamic acid (2), food intolerance (1), and hepatic cirrhosis (3)).

Dotted lines indicate upper limits of excretion in normal subjects.

Conversion: SI to traditional units-Oxalate: $1 \mathrm{mmol} / 24 \mathrm{~h} \approx 90 \mathrm{mg} / 24 \mathrm{~h}$. Fat: $1 \mathrm{mmol} / 24 \mathrm{~h}=284 \mathrm{mg} / 24 \mathrm{~h}$.

(median faecal fat excretion $52 \mathrm{mmol} / 24 \mathrm{~h}(14.8 \mathrm{~g} / 24 \mathrm{~h})$; range $20-276 \mathrm{mmol} /$ $24 \mathrm{~h}(5 \cdot 7-78 \mathrm{~g} / 24 \mathrm{~h})$ ), 23 had hyperoxaluria (median urinary oxalate excretion $0.73 \mathrm{mmol} / 24 \mathrm{~h}(92 \mathrm{mg} / 24 \mathrm{~h})$; range $0.28-2.35 \mathrm{mmol} / 24 \mathrm{~h}(35-296 \mathrm{mg} / 24 \mathrm{~h})$; normal $<0.44 \mathrm{mmol} / 24 \mathrm{~h}(56 \mathrm{mg} / 24 \mathrm{~h}))$ and two gave false negative results due to pancreatic insufficiency and Crohn's disease. Urinary oxalate excretion was significantly lower in the 25 patients without steatorrhoea (median urinary oxalate excretion $0.31 \mathrm{mmol} / 24 \mathrm{~h}(39 \mathrm{mg} / 24 \mathrm{~h})$; range $0.05-0.95 \mathrm{mmol} / 24 \mathrm{~h}$ $(6-120 \mathrm{mg} / 24 \mathrm{~h}))(\mathrm{p}<0.002$, Wilcoxon's two tailed rank sum test). False positive results (urinary oxalate excretion $>0.44 \mathrm{mmol} / 24 \mathrm{~h}(56 \mathrm{mg} / 24 \mathrm{~h}$ )) occurred in three patients with terminal ileal Crohn's disease or resection of the ileum, or both, two with cirrhosis, two with recurrent acute pancreatitis, and one with the irritable bowel syndrome. The predictive value of normal urinary oxalate excretion for normal faecal fat excretion was $89 \%$, and that of hyperoxaluria for steatorrhoea $74 \%$.

\section{Comment}

The simplified oxalate loading test identified all but two of the 25 patients with steatorrhoea. The false negative results may have been due to consumption of a high calcium diet, ${ }^{2}$ failure to take the sodium oxalate load, incomplete urine collection, or occult colonic disease. ${ }^{3}$ Possible explanations of the eight false positive results include a diet containing excess oxalate ${ }^{2}$ consumption of the oxalate load other than with a meal, ${ }^{1}$ incomplete collection of faeces, primary hyperoxaluria, and malabsorption of bile acid due to terminal disease or resection of the ileum. ${ }^{3}$

The modified oxalate loading test is a convenient screening procedure for steatorrhoea. In patients with hyperoxaluria malabsorption of fat requires formal confirmation and oxalate urolithiasis should also be considered. Patients who prove not to have steatorrhoea may have malabsorption of bile acids. In patients with normal urinary oxalate excretion, however, faecal collection may be rendered entirely unnecessary.

We thank Mr A R Williams and the pharmacy staff of this hospital for supplying the sodium oxalate capsules.

${ }^{1}$ Chadwick VS, Modha K, Dowling RH. Mechanism of hyperoxaluria in patients with ileal dysfunction. $N$ Engl f Med 1973;289:172-6.

${ }^{2}$ Earnest DL, Johnson G, Williams HE, Admirand WH. Hyperoxaluria in patients with ileal resection: an abnormality in dietary oxalate absorption. Gastroenterology 1974;66:1114-22.

3 Dobbins JW, Binder HJ. Importance of the colon in enteric hyperoxaluria. $N$ Engl f Med 1977;296:298-301.

4 Andersson $\mathrm{H}$, Gillberg R. Urinary oxalate on a high oxalate diet as a clinical test of malabsorption. Lancet 1977;ii:677-9.

5 Rampton DS, Kasidas GP, Rose GA, Sarner M. Oxalate loading test: a screening test for steatorrhoea. Gut 1979;20:1089-94.

(Accepted 14 February 1984)

University College Hospital, London WC1E 6AU

D S RAMPTON, DPHIL, MRCP, clinical lecturer, department of medicine A D MCCULLOUGH, BSC, MD, registrar, department of chemical pathology JOLANTA S SABBAT, MB, BS, senior house officer, department of chemical pathology

J R SALISBURY, BSC, MB, senior house officer, department of chemical pathology

F V FLYNN, MD, FRCPATH, professor of chemical pathology

M SARNER, MD, FRCP, consultant physician, department of gastroenterology Correspondence to: Dr M Sarner.

\section{Testicular carcinoma in situ in children with the androgen insensitivity (testicular feminisation) syndrome}

Patients with the androgen insensitivity syndrome show a predisposition to germ cell tumours in the adult testis. ${ }^{1}$ In other groups at risk of germ cell malignancies, such as patients with maldescent of the testes, the tumour may be preceded by carcinoma in situ many years before there is overt evidence of neoplasm. ${ }^{23}$ We therefore investigated whether carcinomatous changes could be seen in children with the androgen insensitivity syndrome.

\section{Patients, methods, and results}

We studied 12 consecutive patients with the androgen insensitivity syndrome (median age 6 years (range 2 months to 19 years)). All had 46,XY karyotype and a female phenotype. Four had complete and eight incomplete androgen insensitivity syndrome. In all cases gonadal tissue was removed for prophylactic or diagnostic reasons rather than because a tumour had formed. Samples of testicular tissue were obtained from 20 boys after sudden unexpected death ${ }^{4}$ who were matched for age and served as controls. 
Testicular tissue was prepared for light microscopy and measurement of nuclear DNA as described previously. ${ }^{25}$ In each specimen the DNA content of the nuclei of at least 100 germ cells was measured after these cells had been classified as infantile germ cells of normal appearance, carcinoma in situ germ cells, or germ cells with non-specific abnormalities (figure (top)).
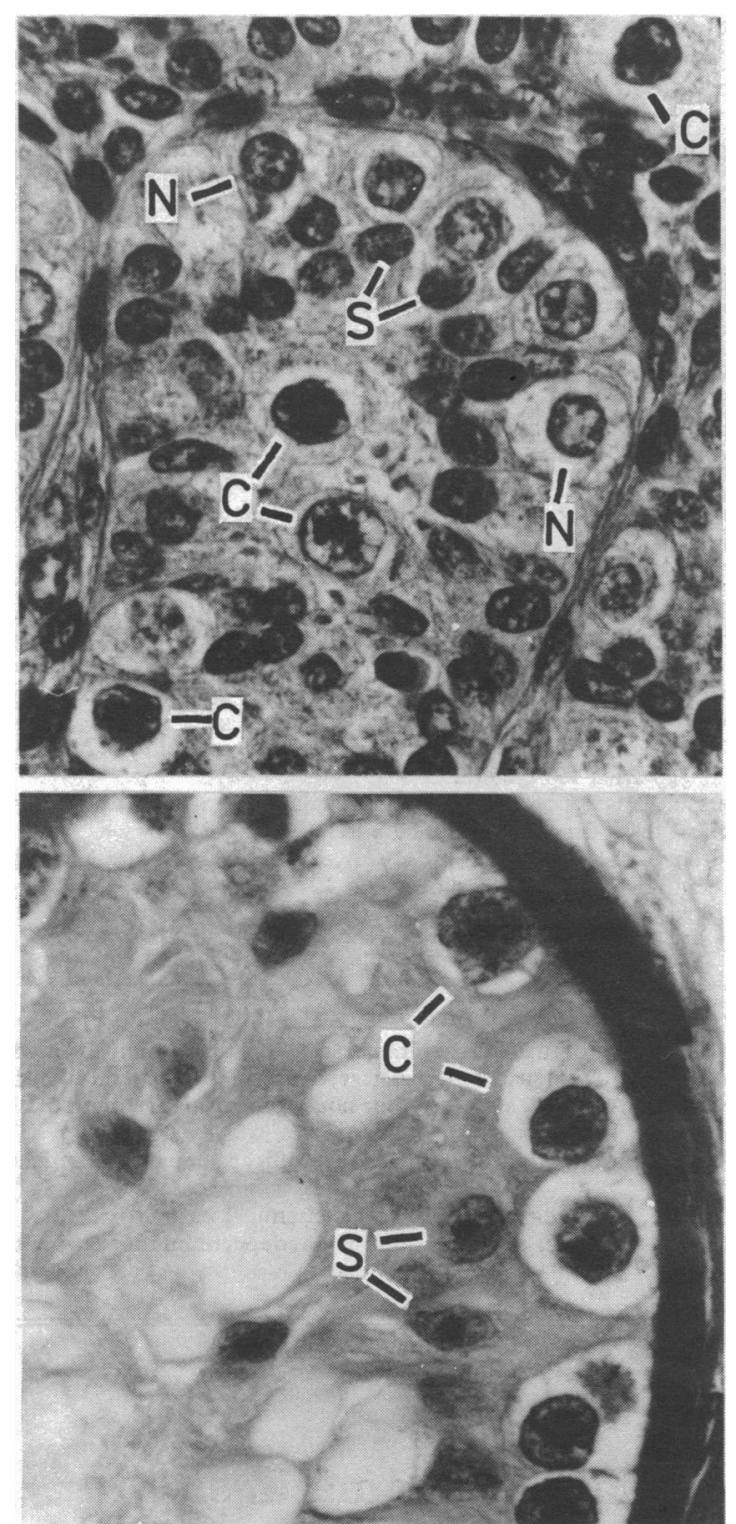

Carcinoma in situ. Top: Prepubertal pattern (immature seminiferous tubules containing immature Sertoli cells $(S)$, carcinoma in situ germ cells (C), and normal infantile germ cells (N)). Bottom: Adult pattern (mature seminiferous tubules containing mature Sertoli cells (S) and carcinoma in situ germ cells (C). Large irregular nuclei contain coarse clumps of chromatin and several nucleoli. Morphological appearance of carcinoma in situ germ cells resembles that of prepubertal lesion). ( $\times 900$ (original magnification) Iron haematoxylin and eosin stain.)

Carcinoma in situ germ cells were found in three of the eight patients with incomplete androgen insensitivity syndrome, who were 14 years, 13 years, and 2 months old. In the right gonad of the oldest boy the carcinom in situ lesion was of the type found in adults (fig (bottom))..$^{3}$ The left testis, which had been removed when he was 2, was not available for study. Each testis of both the other patients had immature seminiferous tubules containing carcinoma in situ germ cells that were morphologically identical with those seen in adults, together with germ cells of normal appearance and cells with nonspecific abnormalities.

A highly aneuploid distribution pattern of DNA in the nuclei of carcinoma in situ germ cells was found in all five gonads containing these cells (median DNA content 3.3-3.9 c). In contrast, all the normal germ cells and most of those with non-specific abnormal morphology from patients and controls had a DNA content within the normal diploid range.

\section{Comment}

We found unexpected intratubular neoplasia in the testicles of two prepubertal and one pubertal patient out of 12 with the androgen insensitivity syndrome, although in no case had a tumour been diagnosed clinically. The finding of aneuploid distribution patterns of DNA in the carcinoma in situ germ cells confirmed that they were premalignant. $^{2}$ Thus, although germ cell tumours are seldom diagnosed in patients with the androgen insensitivity syndrome until several years after puberty, ${ }^{1}$ these neoplasms may originate from infantile germ cells with carcinomatous changes that can be detected as early as 2 months.

Orchidectomy because of the risk of malignancy is generally not advised in patients with the androgen insensitivity syndrome until after puberty. ${ }^{1}$ As germ cell tumours may occur in patients as young as $14,{ }^{1}$ however, and in view of our finding of unsuspected carcinoma in situ in three of 12 children with the androgen insensitivity syndrome, testicular biopsy is warranted as soon as the syndrome is diagnosed. Finding carcinoma in situ in a child with the androgen insensitivity syndrome should indicate immediate orchidectomy. As we do not know the chances of diagnosing carcinoma in situ in the prepubertal testis from a single biopsy specimen, a negative finding in childhood should be confirmed by further biopsy at puberty if orchidectomy is not performed.

This work was supported by grants from the Danish Cancer Society $(26 / 82)$ and the research foundation of the Queen Louise Children's Hospital $(2-12 / 79)$.

${ }^{1}$ Scully RE. Neoplasia associated with anomalous sexual development and abnormal sex chromosomes. Pediatric and Adolescent Endocrinology $1981 ; 8: 203-17$

${ }^{2}$ Müller J, Skakkebaek NE, Nielsen O, Graem N. Cryptorchidism and testis cancer: atypical infantile germ cells followed by carcinoma-in-situ and invasive carcinoma in adult age. Cancer (in press).

${ }^{3}$ Skakkebaek NE, Berthelsen JG, Müller J. Carcinoma-in-situ of the undescended testis. Urol Clin North Am 1982;9:377-85.

4 Müller J, Skakkebaek NE. Quantification of germ cells and seminiferous tubules by stereological examination of testicles from 50 boys who suffered from sudden death. Int $\mathcal{F}$ Androl 1983;6:143-56.

5 Müller J, Skakkebaek NE. Abnormal germ cells in maldescended testes: a study of cell density, nuclear size and DNA content in testicular biopsies from 50 boys. $\mathcal{F}$ Urol 1984;131:730-3.

(Accepted 8 February 1984)

Laboratory of Reproductive Biology, University Department of Obstetrics and Gynaecology Y, Rigshospitalet, DK-2100 Copenhagen $\emptyset$, Denmark

JØRN MULLLER, MD, senior research fellow (and university department of paediatrics $G$ )

NIELS E SKAKKEBAEK, $M D$, professor (and university department of paediatrics, Hvidovre Hospital, Copenhagen)

Correspondence to: Dr J Müller.

ONE HUNDRED YEARS AGO At this season of the year we are accustomed to hear of sad fatalities arising from the accidental ignition of the highly inflammable materials which usually compose the "dresses" of females. Although many practical suggestions have been made from time to time with the view of popularising uninflammabledress materials, the use of such incombustible articles of apparel does not appear to have found favour with the fair sex. Tungstate of soda has been the material most frequently employed to render light fabrics uninflammable; it fulfils the purpose admirably, but its high cost has been an objection to its use. Patera's formulae have stood successfully frequent trials of their efficacy. One of these preparations is made by dissolving three parts by weight of biborate of soda, and two and a quarter parts of sulphate of magnesia, in twenty parts of water. Fabrics soaked in this solution become coated with a borate of magnesia, which is insoluble in hot or cold water, and is a good resistant of fire. The other preparation is a mixture of sulphate of ammonia with sulphate of lime, or gypsum, in proportions of one part of sulphate of ammonia with two parts of gypsum. The gypsum is said to form with the ammonia a double sulphate which has not the disagreeable properties of the ammonia-salt. The action of this preparation seems to be twofold-first, in coating the fibres of the material to be protected, and also in the production, when the material is brought to a red heat, of volatile ammonia, which tends to smother flame. (British Medical fournal $1884 ; \mathrm{i}: 72$.) 